\section{WEBOVÁ PREZENTACE KATEGORIZACE ZDRAVOTNICKÉ TECHNIKY}

\section{Kristýna Matušková}

\section{Anotace}

Třídění zdravotnických prostředků je nedílnou součástí zdravotnického systému $v$ celém svém kontextu. Klasifikační a nomenklaturní systémy slouží $\mathrm{k}$ identifikaci zdravotnických prostředků, tedy k vlastnímu popisu výrobků a orientaci např́íc produktovou hierarchií. Systematizační nástroje se tak stávají důležitou součástí takřka všech procesních úrovní.

Ústav zdravotnických informací a statistiky ČR dlouhodobě realizuje správu českých překladů mezinárodních klasifikací užívaných ve zdravotnictví a vývoj vlastních klasifikací, at již prímým kontaktem $s$ garantujícími mezinárodními organizacemi (především WHO) nebo na základě pověření Ministerstva zdravotnictví.

\section{Klíčová slova}

klasifikace zdravotnických prostředků, Kategorizace zdravotnické techniky, zdravotnické prostředky, Seznam zdravotních výkonů, Národního zdravotnický informační systém

\section{Úvod}

Kategorizace zdravotnické techniky (KZT), dlouhodobě řešena Ústavem zdravotnických informací a statistiky ČR (ÚZIS ČR), vychází z potřeby jednotné klasifikace $v$ ČR používaných skupin zdravotnické techniky a identifikace těchto skupin ve sběrech dat Národního zdravotnického informačního systému (NZIS) spravovaného ÚZIS ČR.

Vzhledem k objemu položek samotné kategorizace (kategorií), složitosti hierarchie a množství informací v KZT obsažených, je dosavadní forma publikace poskytována ve formě jednorozměrné tabulky. Takový model Ize obecně považovat za nedostatečný, proto ÚZIS ČR zadal vytvoření webové platformy pro prezentaci struktury KZT s možností vyhledávání položek (browser)

\section{KZT ve vazbě na mezinárodně uznávané klasifikační systémy}

Samotná kategorizace vychází z analýzy vnitrostátních právních předpisů, právních předpisů Evropské unie, mezinárodních světových norem a celosvětově nejrozšiřrenějších nomenklatur zdravotnických prostředků (např. Global Medical Device Nomenclature, Universal Medical Device Nomenclature System, United Nations Standards Products and Services Code, Systematized Nomenclature of Medicine Clinical Terms, Classificazione Nazionale dei Dispositivi medici atd.)

Za myšlenkou nezbytné návaznosti na mezinárodně uznávané standardy, stojí představa jednotného používání nomenklatury zdravotnických prostředků (ZP) ve všech členských státech Evropské unie, která by tak umožnila spolupráci mezi př́slušnými kompetentními autoritami státu, poskytovateli zdravotní péče, výrobci, distributory, notifikovanými osobami a ostatními zainteresovanými subjekty.

Není proto s podivem, že současná podoba konceptuálního datového modelu KZT vykazuje právě některé znaky typické pro mezinárodně uznávané standardy.

\section{Systémy klasifikace ZP na národní úrovni}

Zásadní roli, v iniciální fázi vývoje projektu KZT, samozřejmě sehrály i v tuzemsku dostupné, informační zdroje.
Informační systém sledování nákupů zdravotnických přístrojů

Jedná se o systém vyvinutý Fakultou biomedicínského inženýrství ČVUT v Praze (FBMI ČVUT). Systém je primárně určený pro prezentaci dat o realizovaných nákupech zdravotnických př́strojů v letech 2010-2014. Uživatelem licence tohoto nástroje je Ministerstvo zdravotnictví ČR [1].

Výstup projektu Podpora systematizace přístrojů (POSYP)

POSYP byl realizovaný Národním referenčním centrem (NRC) v letech 2009-2013. V oblasti přístrojové techniky šlo zejména o revizi př́strojové části databáze Seznamu zdravotních výkonů (SZV).

NRC si kladlo za cíl přiřadit přístroje obsažené v databázi SZV k jednotlivým obecným názvưm kategorií př́strojové techniky a zajistit tak způsob jejich jednotného členění = SYSTEMATIZACE.

\section{Databáze Seznamu zdravotních výkonů (SZV)}

Tato databáze zpřístupňuje údaje registračních listů Seznamu zdravotních výkonů, včetně informace o navázaných zdravotnických přístrojích, resp. jejich skupinách dle interního číselníku „Přístroje" [2].

Datový portál ÚZIS ČR zajištujij́cí automatizovaný sběr dat o př́istrojích v rámci:

a) statistického šetření Ministerstva zdravotnictví ČR prostřednictvím Ročního výkazu o přístrojovém vybavení zdravotnického zařízení (T1) a Ročního výkazu o nákladech na nákup zdravotnické techniky a speciálního zdravotnického materiálu (T2) [3].

b) Národního registru hrazených zdravotních služeb (NRHZS) zřízeného Novelizací zákona č. 372/2011 Sb. o zdravotních službách a podmínkách jejich poskytování (zákon o zdravotních službách), a to zákonem č. 147/2016 Sb [4]. Jedná se o data o věcném, technickém a personálním vybavení jednotlivých pracovišt', zejména vycházející z dat Smlouvy o poskytování a úhradě hrazených služeb a její Přílohy č. 2 [5].

c) Projektu DRG Restart v Referenční síti nemocnic. V údajích o hmotném majetku, které vychází z metodického standardu oceňování hospitalizačních př́ipadů, Ize identifikovat prístroje dle typu pracoviště [6].

Registr zdravotnických prostředků (RZPRO)

V současné době veškeré údaje spravované v RZPRO slouží k plnění povinností České republiky souvisejících s předáváním údajů do Eudamed [7]. RZPRO je nástrojem poskytujícím komplexní informace o ZP uvedených na český trh [8].

\section{KZT jako „unikátní“" nástroj}

Kategorizace svým obsahem zohledňuje veškeré uváděné národní systémy. Využita může být např. jako podpůrný zdroj pro kultivaci sběrů dat (výkaznictví v rámci statistické služby Ministerstva zdravotnictví, Roční výkaz o přístrojovém vybavení zdravotnického zařízení T1), ale i ke kultivaci Seznamu zdravotních výkonů (SZV), kde by data obsažená v kategorizačním stromu nahradila nejednotný číselník přístrojů. Dále i jako zdroj informací pro potřeby strategického plánování prostřednictvím standardizovaného mapování regionálního pokrytí diagnostickými a terapeutickými př́stroji z dat Národního registru hrazených zdravotních služeb (NRHZS), případně jako reálný datový podklad ke standardizaci oceňování pro potřeby CZ-DRG.

Přidružená metodika KZT však sama o sobě nedefinuje způsoby samotného využití kategorizace v praxi. Možností je mnoho a vždy budou odpovídat záměru daného subjektu, který se rozhodne pro její aplikaci. 
Od elektronicky funkčního kategorizační systému (browser KZT) si slibujeme efektivnější práci s kategorizací a možnost zařazení přístrojů a kódování v běžné praxi.

\section{Literatura}

[1.] Informační systém sledování nákupů zdravotnických přistrojů: Závěrečná zpráva o řešeni grantu Interni grantové agentury MZ ČR. Kladno: České vysoké učení technické v Praze, Katedra biomedicínské techniky FBMI ČVUT, 2015.

[2.] Seznam zdravotních výkonů [online]. Palackého nám. 4, 12801 Praha 2: ÚZIS ČR, 2016 [cit. 2018-12-06]. Dostupné z: https://szv.mzcr.cz/

[3.] Přístrojové vybavení: Výkazy ÚZIS ČR [online]. Palackého nám. 4, 128 01 Praha 2: ÚZIS ČR, 2018 [cit. 2018-12-06]. Dostupné z: http://www. uzis.cz/vykazy/vykazy-rok-2017\#T

[4.] Zákon č. 147/2016 Sb., kterým se méní zákon č. 372/2011 Sb., o zdravotních službách a podmínkách jejich poskytování (zákon o zdravotních službách), ve znění pozdějších předpisů. In: Sbírka zákonů. 17. 5. 2016. ISSN ISSN 1211-1244.

[5.] Postup uzavírání smluv pro jednotlivé typy poskytovatelů zdravotních služeb. Https://www.vzp.cz/ [online]. Praha: Všeobecná zdravotní pojištovna ČR, 2018 [cit. 2018-12-06]. Dostupné z: https://www.vzp. cz/poskytovatele/smluvni-vztahy/postup-uzavirani-smluv-pro-zdravotnicke-zarizeni

[6.] Oceňování akutní lůžkové péče. DRG Restart [online]. Praha: Ústav zdravotnických informací a statistiky ČR, 2018 [cit. 2018-12-06].

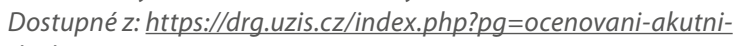
-luzkove-pece

[7.] EUDAMED: European Database on Medical Devices. The European Commission [online]. Brussel, Belgium: The European Commission, 2018 [cit. 2018-12-06]. Dostupné z: http://lec.europa.eu/idabc/en/ document/2256/5637.html

[8.] Registr Zdravotnických Prostředků [online]. Praha: Státní ústav pro kontrolu léćiv, Ústav zdravotnických informacía statistiky CR, 2018 [cit. 2018-12-07]. Dostupné z: https://eregpublicsecure.ksrzis.cz/ Registr/RZPRO

\section{Kontakt}

Kristýna Matušková

Oddělení klinických klasifikací

ÚZIS ČR

Palackého náměstí 4, 12800 - Praha 2

e-mail:kzt@uzis.cz

https://www.uzis.cz/index.php?pg=registry-sber-dat--klasifikace--kategorizace-zdravotnicke-techniky 